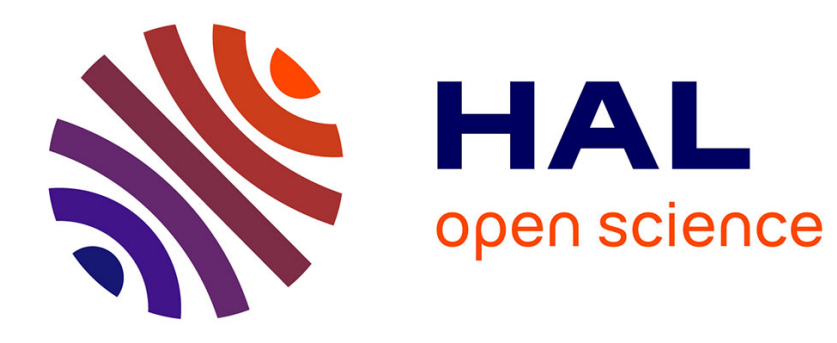

\title{
The determinants of recidivism among ex-prisoners: a survival analysis on French data
}

\author{
Benjamin Monnery
}

\section{To cite this version:}

Benjamin Monnery. The determinants of recidivism among ex-prisoners: a survival analysis on French data. 2013. halshs-00822847

\author{
HAL Id: halshs-00822847 \\ https://shs.hal.science/halshs-00822847 \\ Preprint submitted on 15 May 2013
}

HAL is a multi-disciplinary open access archive for the deposit and dissemination of scientific research documents, whether they are published or not. The documents may come from teaching and research institutions in France or abroad, or from public or private research centers.
L'archive ouverte pluridisciplinaire HAL, est destinée au dépôt et à la diffusion de documents scientifiques de niveau recherche, publiés ou non, émanant des établissements d'enseignement et de recherche français ou étrangers, des laboratoires publics ou privés. 
The determinants of recidivism among ex-prisoners: a survival analysis on French data

Benjamin Monnery 


\section{GATE Groupe d'Analyse et de Théorie Économique Lyon-St Étienne}

93, chemin des Mouilles 69130 Ecully - France

Tel. +33(0)4 72866060

Fax $+33(0) 472866090$

6, rue Basse des Rives 42023 Saint-Etienne cedex 02 - France

Tel. +33 (0)4 77421960

Fax. +33 (0)4 77421950

Messagerie électronique / Email : gate@gate.cnrs.fr

Téléchargement / Download : http://www.gate.cnrs.fr - Publications / Working Papers 


\title{
The determinants of recidivism among ex-prisoners : a survival analysis on French data
}

\author{
Benjamin Monnery ${ }^{\dagger}$ \\ GATE Lyon St-Etienne
}

April 2013

\begin{abstract}
This article explores the main determinants of the hazard of recidivism among ex-prisoners. We use a nationally-representative sample of prisoners released in 1996-1997 in France, drawn from a 5-year follow-up survey run by the French correctional administration. We estimate semiparametric duration models which deal with violations of the proportional hazards hypothesis. Our results confirm the importance of gender, age, nationality, access to employment and prior convictions on recidivism within five years after release from prison. We also find significant differences in hazards of recidivism by type of initial offense, penal status at entry, and type of release (early release under parole, etc.), while controlling for prison fixed effects. Finally, our study casts doubt on the influence of certain variables (marital status at entry, education, homelessness) and on the effectiveness of semi-liberté as a way to prevent recidivism.
\end{abstract}

JEL : C41, K42

Keywords : economics of crime, recidivism, duration models

\section{Acknowledgment}

The micro-data used in this study were obtained thanks to the support of the French correctional administration (DAP) and the Ministry of Justice and Freedoms. I am deeply grateful to Annie Kensey from the DAP for her precious help in obtaining the dataset. I also thank my supervisor Jean-Yves Lesueur for his support and his comments during this research project. All remaining errors are mine.

\footnotetext{
${ }^{\dagger}$ Université de Lyon, Lyon, F-69007, France ; CNRS, GATE Lyon Saint-Etienne, Ecully, F-69130, France Contact : 93, chemin des Mouilles - B.P.167 - 69131 - ECULLY cedex

Email : monnery@gate.cnrs.fr
} 


\section{Introduction}

According to the last figures published by the French correctional administration ${ }^{1}$, the number of people incarcerated in French prisons hit a historic high in December 2012 with 67,674 prisoners $(+3,7 \%$ over the last 12 months $)$ : this figure represents an incarceration rate of 103 for 100,000 inhabitants. Since French prisons have a total capacity of only 56,953, most facilities face overcrowding. Moreover, each year, more than 80,000 prisoners are released back into society. One of the missions of the french judicial and correctional system is to rehabilitate prisoners, facilitate their reentry, and prevent recidivism ${ }^{2}$ and return to prison. Thus it is important to measure recidivism among ex-prisoners, better understand its determinants, and eventually offer possible solutions.

The most recent survey on recidivism in France, which is about a cohort of detainees released between June and December 2002, suggests that $59 \%$ of ex-prisoners are re-convicted in the next five years following release, $80 \%$ of them returning back to prison (Kensey and Benaouda, 2011). Besides its frequency, recidivism occurs rapidly, as $75 \%$ of recidivists reoffend in the first two years after release. International surveys show that France is no exception : in England and Wales for example, $57,6 \%$ of the prisoners released in 1998 were convicted again in the two years following release (Bowles and Florackis, 2007). In the United States, the most recent federal survey suggests that about $70 \%$ of those released in 1994 were rearrested in the next three years (Langan and Levin, 2002). These high recidivism rates generate substantial additional costs to society, whether direct or indirect (costs to the victims, additional police and justice expenditures, cost of incarceration, loss of human and social capital, loss of production while incarcerated, etc.).

Economists pay increasing attention to the study of crime and recidivism, notably since the seminal work of Gary Becker. His rational-choice crime model (Becker, 1968) led to the development of the field of economics of crime, which applies microeconomic concepts and methods to the study of illegal behaviors and repressive institutions. Following Becker, many researchers used econometrics and experimental economics to test the empirical validity of this model ; however, to this day, most research rely on a small set of countries (US, UK, Italy and a few others). Conversely, there are only a few analyses on French data, which do not take into account the time-dependent aspect of recidivism processes (Kensey and Benaouda (2011) ; Maurin and Ouss (2009)). This article attempts to contribute to this topic by applying duration models to French data.

The article is structured as follows : the first section briefly reviews the main determinants of recidivism identified by prior research. The second section presents the dataset, while the third section discusses the model specification we chose. The fourth section presents the results obtained in terms of instantaneous probability of recidivism. Finally, the fifth section concludes and discusses the limitations of this study.

\section{The determinants of recidivism : survey of the literature}

The analysis of recidivism among ex-prisoners relates to a much broader research field studying delinquency and crime. In this field, some scholars focus on understanding what leads to crim-

\footnotetext{
${ }^{1}$ Official monthly statistics can be obtained at www.justice.gouv.fr/prison-et-reinsertion-10036/ les-chiffres-clefs-10041/statistiques-mensuelles-de-la-population-detenue-et-ecrouee-23435. html

${ }^{2}$ In this study, the term "recidivism" only stands for "re-conviction", i.e. the fact that an ex-prisoner commits a new offense and is re-convicted after release
} 
inal behavior, whereas others attempt to better capture the long-term pathways to desistance (Sampson and Laub, 2003). Overall, the existing literature relies on four main types of factors in the study of individual criminal behavior :

- Sociodemographic factors : sex, age, ethnic origin, marital status, education level, standard of living (access to employment, occupation, income), etc.

- Cognitive and psychological factors : risk aversion, time preferences, motivation, selfcontrol, moral values and emotions ${ }^{3}$, coping skills ${ }^{4}$, mental health, drug addiction, etc.

- Factors related to prior criminal behavior : number of prior convictions, type of offense(s), time passed since last offense, type and duration of sentence(s), etc.

- Environmental and institutional factors : socioeconomic environment ${ }^{5}$ (unemployment, poverty, inequality, anomie, etc.), repressive institutions (police, justice), family ties (capacity to provide financial and psychological support, to exert positive social control), neighborhood effects, peer effects, etc.

Among the many existing theories of crime (Barlow and Kauzlarich, 2010), economists dominantly rely on rational choice theory. More precisely, Becker's theoretical model (1968) suggests that agents face a trade-off between legitimate and illegitimate activities and choose the strategy that maximizes their expected utility. Naturally, further theoretical developments introduced additional factors and greater complexity (see for example Van Winden and Ash (2012) for a behavioral crime model taking cognitive and emotional factors into account) but utility-maximization remains central. The most straightforward prediction of the rational choice crime model is that criminals, like all other agents, react to incentives, either positive or negative : it notably puts emphasis on the role of deterrence on criminal behavior (through probability and cost of apprehension). It also offers a theoretical explanation for many stylized facts such as the beneficial role of eduction and aging for example.

Many experiments have been run over the years to test the validity of Becker's rational criminal model. Farrington (2003) reviews all the randomized experiments completed in United Kingdom : most of them do not specifically address recidivism but study illegal or antisocial behaviors such as lying or stealing money. However, several experiments focus on evaluating the effect of different programs on ex-prisoners reentry : Folkard et al. (1976) for example evaluates how changes in supervision intensity during probation affect recidivism. More recently, Bierie (2009) compares recidivism rates between convicts who were randomly assigned to a traditional prison or to a boot camp : his results suggest that tougher conditions of detention lead to greater probability of recidivism. In a lab experiment, DeAngelo and Charness (2012) test the deterrent effect of penalties on recidivism (measured as repeated speeding by participants) : among other things, they find that individuals choose to commit more offenses and recidivate more often when penalties decrease.

Econometric studies of the effect of deterrence on recidivism have long been unsatisfactory due to the presence of endogeneity and selection bias. However, recent empirical work strongly confirms a specific deterrent effect of prison sentences : Maurin and Ouss (2009) for example study the effect of collective sentence reductions on ex-inmates' recidivism in France : their

\footnotetext{
${ }^{3}$ See Svensson et al. (2013)) for an empirical study of the role of moral values, anticipated shame and guilt on juvenile delinquency in the Netherlands

${ }^{4}$ See Zamble and Quinsey (1997)

${ }^{5}$ See Kubrin and Stewart (2006) for the first empirical investigation on the subject
} 
results suggest that reducing prison sentences for all prisoners leads to increased probability of recidivism. Taking advantage of a large reform in Italy, Drago et al. (2009) exploit random variations in expected sentences in case of recidivism : they show that the probability of recidivism diminishes when expected sentence increases.

Beyond deterrence, a growing part of recidivism studies attempt to identify the causal effects of imprisonment. Prison is often considered as a school of crime where inmates acquire "criminal capital" (which can be a mix of social and human capital), lose attachment to their social network (social bond theory - Hirschi, 1969) and from where they leave as labelled criminals (labeling theory - Bernburg et al. (2006)). But imprisonment can conversely be viewed as a way to rehabilitate convicts and deter future offending. Even though a complete survey of these topics is far beyond the scope of this article, it is noteworthy that this research field is growing and combines different approaches to document the effect of imprisonment on recidivism. For example, Di Tella and Schargrodsky (2013) study the impact of the type of sentence in Argentina : more precisely, they show that defendants who serve pre-trial time under electronic monitoring instead of pre-trial detention are significantly less likely to recidivate (controlling for selection bias through IV). Using US data, Chen and Shapiro (2007), followed by Drago et al. (2011) in Italy, focus on the effect of prison conditions on recidivism : they find that tougher prison conditions (in terms of security levels or geographical isolation) lead to greater risk of recidivism after release. Finally, recent work investigates the role played by social interactions in prison : for example, Bayer et al. (2009) identify peer effects among a sample of 8,000 young inmates in Florida. Their results specifically suggest that "exposure to peers with a history of committing a particular crime increases the probability that an individual who has already committed the same type of crime recidivates with that crime". Such exogenous interactions ${ }^{6}$ may be driven by networks formation and exchange of specific human capital while in prison. Using individual data from Italy, Drago and Galbiati (2012) are able to identify endogenous social interactions among inmates of the same nationality, such that peers' recidivism behavior has a positive causal effect on one's behavior.

Since the early work of Schmidt and Witte (1989), a large amount of recidivism studies use duration analysis (instead of binary models) in order to investigate the dynamics of recidivism and to account for state dependency. Indeed, it is well known that the instantaneous risk of recidivism decreases over time, starting very high at date of release (or soon after) and then slowly decreasing close to zero after several years. Using semi-parametric Cox models, Duwe and Clark (2013) attempt to evaluate the effect of visits in prison (number, frequency, timing, types of visitors) on recidivism among Minnesota's ex-prisoners. Amirault and Lussier (2011) investigate the decrease of the predictive power of prior criminal charges on sex offenders' recidivism over time. Skardhamar and Telle (2009) estimate Cox models with shared frailty and time-varying variables to investigate the effect of getting a job on the hazard of recidivism. Similarly, Uggen (2000) evaluates the effectiveness of a US program which randomnly grants jobs to ex-convicts. An alternative to Cox models is the use of parametric models, where the shape of the baseline hazard is explicitely specified : Kim et al. (1993) estimate a Weibull model (including proxies for opportunity cost and probability of arrest) to study the validity of Becker's model among drug offenders. Using UK data, Bowles and Florackis (2007) use exponential and Weibull parametrizations (with shared frailty and stratification) to study the relationship between age and recidivism. Bierens and Carvalho (2002) provide an important contribution by distinguishing two competing risks : violent recidivism and non-violent recidivism. Competing-

\footnotetext{
${ }^{6}$ See Manski (2000)'s classification of social interactions
} 
risks models allow for a better understanding of the complexities of recidivism since the effect of each explanatory variable is estimated for both violent and non-violent recidivism, these two risks being correlated. Another major contribution is the use of split-population models, which split samples into two groups - one capturing those who present a real, non-null risk of recidivism, the other representing those who would never recidivate (no matter how long they were followed). Schmidt and Witte (1989) are one the first scholars to apply this method to the study of recidivism among ex-inmates in the US. More recently, Escarela et al. (2000) mix a split-population model to a competing-risks model on british data. ${ }^{7}$

Overall, most -if not all- research confirms the dramatic influence of gender, age and criminal background on recidivism patterns among ex-prisoners : young males with a criminal record present the highest instantaneous risk of recidivism. These results initally came from US data and have been confirmed in other countries ; this excludes France where no survival analysis of ex-inmates' recidivism has been conducted to our knowledge.

\section{Data}

Our dataset come from a survey run by Annie Kensey and Pierre-Victor Tournier (2005) for the French correctional administration. It is a nationally representative cohort of 2,858 convicted exprisoners released between May 1, 1996 and Avril 30, 1997 in France. Many socio-demographic, judiciary and carceral information is gathered for all sampled releasees. Recidivism is measured as any new conviction registered in one's criminal record in June 2002, hence a follow-up period of at least 5 years after release. Criminal records could not be retrieved or used for 654 exprisoners $^{8}$, therefore we are left with a study sample of 2,204 individuals.

This survey seems to come close to the real recidivism patterns of ex-prisoners for several reasons. First, the follow-up period (more than 5 years) is greater than those used in standard surveys of ex-inmates, and the few existing long-term surveys suggest that a large majority of recidivists reoffend before 5 years after release. Second, recidivism is tracked through a very reliable measure : recidivism is established if at least one new conviction (for an offense commited after release) appears in the official, nationwide criminal records in June 2002, whatever the new sentence. Most surveys generally use rearrest (or reconviction in the same region, e.g. one state of the US) as a measure of recidivism. Finally, we have access to very precise temporal data which gives us the exact number of days between one's release from prison and the date of first reoffending, if any. The reliability of duration models estimates clearly benefits from such precision.

However, using official criminal records has the obvious limitation of capturing only reoffenders who get arrested and convicted. Plus, in France, a convict can obtain -in very rare cases- the withdrawal of his conviction from his criminal record.

Socio-demographic data are extracted from each detainee's personal prison file : prisoners fill these informations at date of entry. Therefore, these variables do not necesseraly capture one's situation at or after release, and their reliability mainly relies on honnesty. Finally, certain variables are of limited precision, such as the education variable, which is dichotomous and only distinguishes between those who went to middle school and those who did not (thus many

\footnotetext{
${ }^{7}$ While attractive, these methods necessitate very long follow-up periods (a decade or more) to distinguish those who are at risk (called persisters) from those who would never recidivate (desisters). Therefore most follow-up surveys do not allow for the use of such methods.

${ }^{8} 653$ criminal records could not be retrieved or used for one of the following reasons : un-matched identity, deceased, incomplete record, recording error. One record was not used because it reflected a very special case of incarceration ("contrainte par corps").
} 
Table 1: Descriptive Statistics $(\mathrm{N}=2204)$

\begin{tabular}{|c|c|c|c|}
\hline Variable & Mean & s.d. & Definition \\
\hline Gender & 0.96 & 0.20 & Male (1) or female $(0)$ \\
\hline Education level & 0.63 & 0.48 & At least Middle school (1) ou lower (0) \\
\hline Employment & 0.50 & 0.50 & Declared having a job (1) or not (0) \\
\hline Marital status & 0.17 & 0.38 & Married (1) or other (0) \\
\hline Nationality & 0.29 & 0.46 & Foreigner (1) or French $(0)$ \\
\hline Homeless & 0.16 & 0.36 & Declared being homeless $(1)$ or not $(0)$ \\
\hline Age at release & 31.89 & 10.11 & Age at release, in years \\
\hline Age $<23$ & 0.18 & 0.39 & \\
\hline $23 \leq$ Age $<28$ & 0.24 & 0.43 & \\
\hline $28 \leq$ Age $<33$ & 0.20 & 0.40 & \\
\hline $33 \leq$ Age $<38$ & 0.14 & 0.34 & \\
\hline Age $\geq 38$ & 0.23 & 0.42 & \\
\hline \multicolumn{4}{|l|}{ Penal status at entry } \\
\hline Short pre-trial detention & 0.40 & 0.49 & Fast procedure* \\
\hline Pre-trial detention & 0.30 & 0.46 & Classic procedure \\
\hline Execution of prison sentence & 0.30 & 0.46 & No pre-trial detention \\
\hline Prior convictions & 2.96 & 3.41 & Number of prior convictions \\
\hline None & 0.27 & 0.44 & \\
\hline One & 0.18 & 0.38 & \\
\hline Two or three & 0.23 & 0.42 & \\
\hline Four and more & 0.32 & 0.47 & \\
\hline Number of cases & 1.32 & 0.76 & Number of cases which led to conviction \\
\hline Time served & 13.64 & 23.51 & Duration of effective incarceration, in months \\
\hline Libération conditionnelle & 0.12 & 0.32 & Released under parole (1) or not (0) \\
\hline Placement à l'extérieur & 0.02 & 0.14 & Placement à l'extérieur (1) or not (0) \\
\hline Semi-liberté & 0.08 & 0.28 & Semi-liberté (1) or not (0) \\
\hline Type of initial offense & & & Of the principal offense if multiple \\
\hline Against persons & 0.29 & 0.45 & Violent crimes, rape, homicide \\
\hline Against property & 0.36 & 0.48 & Stealing, swindle, etc. \\
\hline Drug-related & 0.16 & 0.36 & Trafficking, selling, use \\
\hline Other & 0.19 & 0.40 & Administrative, driving and other offenses \\
\hline Year of release & 0.37 & 0.48 & Released in $1997(1)$ or in $1996(0)$ \\
\hline Recidivism & 0.58 & 0.49 & At least one new conviction \\
\hline Return to prison & 0.44 & 0.50 & New sentence to prison \\
\hline
\end{tabular}

* Fast procedure : immediate trial, in the act, etc.

human capital differences remain unobserved). Table 1 reports a list of all the variables used, as well as their mean, standard deviation and a brief definition.

$96 \%$ of the sample are men, as in the current prison population $(96,6 \%$ on December 1 st, 2012). Only $63 \%$ went to middle school before entry. One half declared they had a job and $17 \%$ declared they were married. The share of foreign prisoners equals $29 \%$, while $16 \%$ described themselves as homeless. The average releasee was 32 years old at exit, but some were under 18 (1\%). $70 \%$ of the sample served pre-trial detention, either for a short or a longer time (procédure rapide or not), and the $30 \%$ remaining were incarcerated after conviction to prison. On average, prisoners had already been convicted three times previously, though $27 \%$ had no criminal record. More than three quarters of the sample were convicted to prison for a single case. Time served 
Figure 1: Smoothed (non-parametric) hazard function

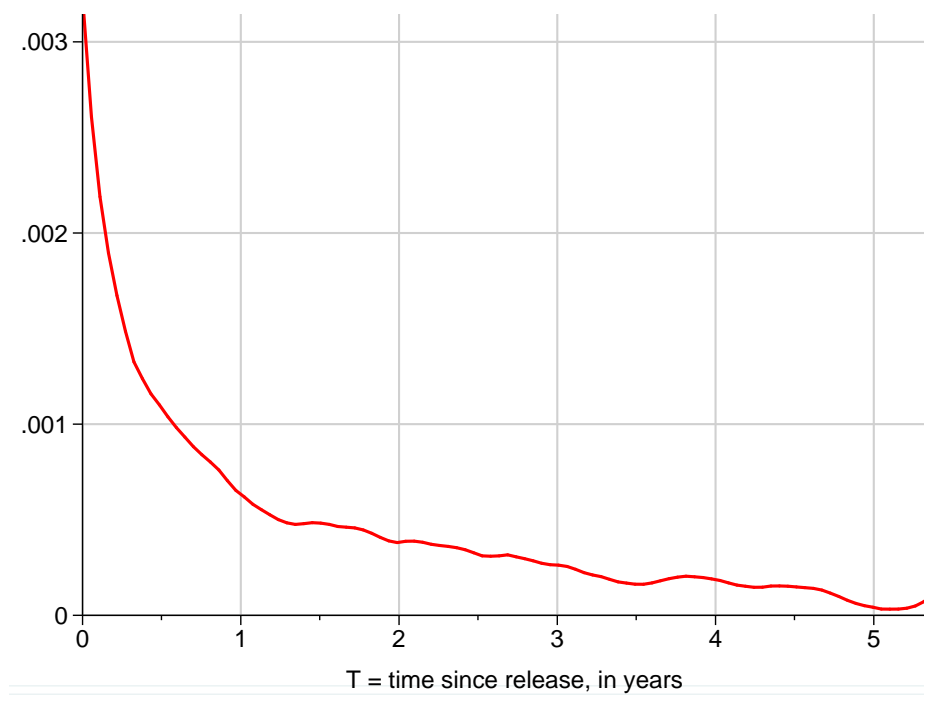

ranges from one day to almost 20 years : it equals 14 months on average, the median time served being 5 months $^{9} .12 \%$ benefited from an early release under parole (libération conditionnelle), $2 \%$ obtained a placement à l'extérieur and $8 \%$ a semi-liberté $e^{10}$. Regarding offense types, $36 \%$ were convicted for property crime, $29 \%$ for violent crime, and $16 \%$ for drug-related offenses ${ }^{11}$. Most prisoners were released in year 1996 (between May 1st and December 31). In terms of recidivism, $58 \%$ of the 2,204 releasees were re-convicted before June 2002 and $44 \%$ went back to prison for a new offense.

Figure 1 gives a graphical representation of recidivism dynamics. More precisely, it shows the evolution of hazard over time ${ }^{12}$, that is the change in the probability of recidivism at time $t$ among those who are still at risk at that time (those who have not reoffended yet, or those who are right-censored). As shown by Figure 1, the hazard is maximal at the time of release, rapidly diminishes until $\mathrm{T}=1$ year, and then gets closer and closer to zero after five years. The shape of this hazard function (monotonically decreasing, convex) is a bit different for what is often observed in other countries (first increasing for a few months, then decreasing and convex) : this is probably because in most foreign studies the duration that is used is the time to rearrest or to reconviction, not the time to reoffense. Therefore, such durations include a lag accounting for the fact that arresting and convicting a criminal takes time.

The non-parametric statistics described above give a very aggregated description of recidivism patterns. However, huge disparities exist between prisoners in terms of recidivsm. Before turning to our econometric analysis, it can be interesting to illustrate survival rates for different groups of prisoners. Figure 2 plots survival functions by gender, age and type of initial offense, three variables that are traditionnaly considered as strong predictors of recidivism : we can notice that the patterns are quite different between men and women and between age brackets (three fourth of those under 23 at release reoffend during the follow-up period, compared to $39 \%$ of the $38+$ group). Moreover, survival rates vary by type of initial offense, those convicted

\footnotetext{
${ }^{9}$ See Kensey and Tournier (2002) for a detailed summary of time served among this sample

${ }^{10}$ These two French legal measures allow a prisoner to go out of prison routinely for several hours or days to do a particular activity, such as working

${ }^{11}$ When one is convicted for multiple offenses, the category of the most serious crime is used

${ }^{12}$ The hazard function is smotthed with Epanechnikov's alternative kernel function, available in Stata
} 
Figure 2: Survival functions by gender, age at release and type of initial offense

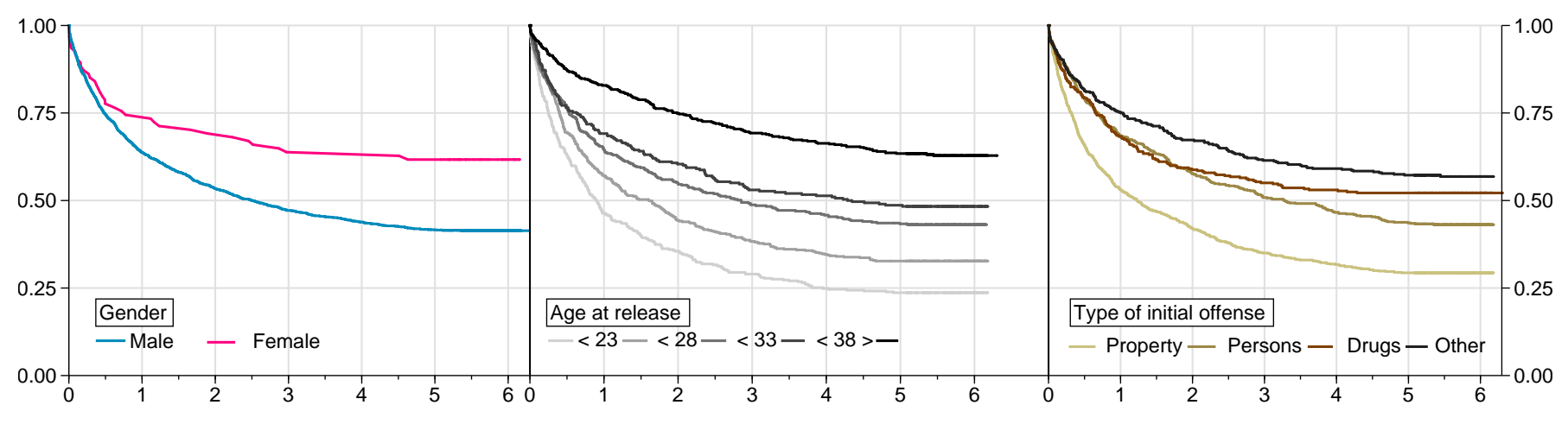

for property crime being the most likely to reoffend. These differences are a first indication of the complexity of recidivism behaviors among ex-prisoners. We now turn to our econometric duration analysis which, by reasoning "everything else equal", allows us to isolate the influence of each covariate on the dynamic of recidivism.

\section{Model specification}

Our model specification attempts to offer a better understanding of recidivism among exprisoners, by identifying its main determinants. It also attempts to capture most inter-individual heterogeneity to limit omited-variable bias.

To do so, all the available socio-demographic variables are included in the model : some of them are considered as major determinants of recidivism in the existing research (gender, age, labor-market status, education) while others have less documented effects but appear relevant (marital status, nationality, homelessness).

Our specification also includes the number of prior convictions, as empirical evidence strongly suggests that prior offending behavior -which precisely indicates whether one has already reoffendedis one of the best predictors of future recidivism. This stylized fact is equivocal : it can suggest that recidivism is a state dependent process (prior convictions have a causal effect on future behavior), but it can also support the selection hypothesis such that individuals are intrinsically heterogenous in terms of crime propensity (spurious correlation due to uncontrolled unobserved heterogeneity). Amirault and Lussier (2011) also show that past convictions lose predictive power over time : we can not study this point here, as our dataset only includes the total number of prior convictions, not their dates.

Additional variables are used in our specification to better capture individual recidivism propensity : first, we include the number of cases which led to imprisonment and the type of offense commited. We also use pre-trial detention (fast procedure, classic procedure, or no pretrial detention), time served ${ }^{13}$, and individual sentence reductions (libération conditionnelle, placement à l'extérieur and semi-liberté). Most prior econometric studies fail to control for pre-trial detention, but this variable may capture a great deal of information concerning one's criminal propensity, as perceived by the judge : indeed, french judges can decide to put highrisk suspects on pre-trial detention and choose a "fast procedure" to incapacitate them. Thus, these variables capture both objective and subjective risk assessments and can therefore serve

\footnotetext{
${ }^{13}$ The causal effect of time served on recidivism is a very debated theoretical and empirical topic. This article does not adress this difficult question, but it is important to control for time served in recidivism studies
} 
as proxies for criminal propensity.

Finally, a dummy variable representing the year of release (1996 or 1997) controls for potential cohort effects : this variable ensures that, if there is systematic unobserved heterogeneity between 1996 releasees and 1997 releasees (for example, they may not face the same institutional or economic environment at release), such cohort effects will not bias our estimates. Similarly, we include prison fixed-effects (last prison of incarceration) so that potential inter-prison differences are controlled for (e.g. prison conditions, in-prison rehabilitative programs). These prison dummies may also capture unobserved heterogeneity between the local economic and social environments prisoners face at release (imperfectly, since we do not have data regarding prison location or residential mobility after release).

Even though our goal is to minimize the risk of omited variable bias, we can not reject it a priori, as several potentially important covariates remain unobserved, such as self-control, motivation, social capital, etc. Duration models applied to recidivism also rely on the too-rarelydiscussed assumption that no systematic change in police and justice practices happened during the follow-up period. If, for example, some types of crime became a priority among police forces during the study period, not controlling for this change through time-varying covariates would lead to mis-specification. Even though several legal reforms were enacted in France during the 1996-2002 period, we regard the assumption above as credible.

\section{Results}

Most survival analyses applied to recidivism rely on Cox's semi-parametric model, where instantaneous probability is characterized as :

$$
h_{i}(t)=h_{0}(t) \cdot \mathrm{e}^{\mathrm{X}_{\mathrm{i}} \beta}
$$

where $h_{0}(t)$ represents the baseline hazard (left unparametrized). This flexible model assumes that each explanatory variable affects hazard in a multiplicative and constant-over-time way. Thus, the shape of the baseline hazard is assumed to be the same for all ex-prisoners, whatever their profile. However, we may think that recidivism dynamics differ between a prisoner convicted for murder and another convicted for drug trafficking, for example (Bowles and Florackis (2007) ; Kim et al. (1993)). Statistical tests (based on the Shoenfeld residuals) tend to confirm this intuition and suggest that several variables violate the proportional-hazards $(\mathrm{PH})$ hypothesis : gender, nationality, pre-detention, sentence reductions and type of initial offense (we denote $Z$ this vector of variables that are supposed to violate the $\mathrm{PH}$ hypothesis) ${ }^{14}$. Such results are not surprising : foreign prisoners, for example, may differ from french detainees not only in terms of their effective criminal dynamics but also in terms of emigration behavior, two possibilities that would violate the $\mathrm{PH}$ assumption. Plus, prisoners released under parole are supervised temporarily at release by probation officers : this supervision may alter parolees' recidivism dynamics compared to unsupervised releasees.

Since non-proportional hazards lead to biased coefficients (toward zero when hazards converge over time) and biased standard errors, it is important to account for the violation of the $\mathrm{PH}$ assumption. Our approach consists in estimating a semi-parametric Cox model with interaction terms between the variables $Z$ and (the log of) time $^{15}$, such that :

\footnotetext{
${ }^{14}$ The results of these tests are available in Table 3 in the appendix

${ }^{15}$ The $\log$ function implies that the effect of an explanatory variable changes over time in a non-linear way, which seems more realistic than a linear function. However, Table 5 shows the results we obtained with $f(t)=t$
} 


$$
h_{i}(t)=h_{0}(t) \cdot \mathrm{e}^{\mathrm{X}_{\mathrm{i}} \beta+\mathrm{Z}_{\mathrm{i}} \theta \ln (\mathrm{t})}
$$

This specification allows each variable $Z \in X$ to have a time-varying effect, i.e. two effects : one on the level of hazard (at all time) and another on the evolution of hazard over time ${ }^{16}$. Not only is this distinction necessary from a methodological standpoint (to relax the PH assumption), it is also useful to better understand recidivism processes among ex-prisoners : indeed, this method enables us to distinguish between prisoners who present a high but fastly-decreasing hazard of recidivism (thereby suggesting the need for an intensive short-term supervision at release) and releasees whose risk is more modest but stable over time. Acknowledging these two dimensions seems critical to better prepare prison releases and improve recidivism prevention.

The results from the time-varying-effects Cox model are shown in Table 2 (expressed as hazard ratios ${ }^{17}$ ). In this model, all the explanatory variables discussed in Section 3 are included, except for type of initial offense which only appears in the vector $Z$ of the variables violating the $\mathrm{PH}$ assumption. This specification minimizes the Bayesian information criterion compared to two alternatives (inclusion of type of offense in $X$ only, or in both $X$ and $Z$ ), as can be seen in Table 4 (appendix). The estimates from Model 1 suggest that the temporal dynamic of recidivism varies significantly from one type of offense to another (Model 3 rejects the hypothesis of a "double effect", on both the hazard at release and its evolution over time). However, noteworthy is the fact that these three specifications lead to very similar results regarding the role played by the other explanatory variables. We now focus on the estimates derived from Model 1.

First, our results show that the effect of gender is two-fold : everything else equal, male releasees experience a $69 \%$ lower hazard of recidivism at release compared to females, but this ranking reverses very rapidly (after 57 days ${ }^{18}$ ) because hazard decreases at a much slower pace among male than among female ex-prisoners. These results suggest that women experience a relatively high risk of recidivism just after release from prison, but that this risk decreases relatively fast : in terms of public policy, it seems that short-term intensive supervision may be particularly appropriate among women. An alternative interpretation (in terms of compositional effects) is that, except for a minority who reoffends quickly, most female releasees desist more easily from crime than males (maybe thanks to a more positive reentry into their families and communities), hence the need for better-targeted supervision and reentry programs.

The next estimates show that neither marital status, nor education, nor homelessness, are associated with a significant change in the instantaneous probability of recidivism. These results seem counterintuitive at first, but recall that these informations are declared by each prisoner at time of entry (not at release), and that their precision is limited (dummy variables). Releasees who declared they had a job at entry face a significantly lower hazard after release ( $12 \%$ lower), which is consistent with rational choice theory (tradeoff between legal and illegal activities). At release, foreign prisoners display a hazard that is much higher than among French releasees (hazard ratio $=2,31$ ) but it diminishes much faster over time (18\% faster), probably because foreigners are more likely to leave the country in the months following release, notably. The estimates for age and age squared show that young releasees are far more likely to recidivate

${ }^{16}$ See for example Box-Steffensmeier (2004) for more details on this method. Noteworthy is the fact that this approach leads to very similar results to those obtained with a Generalized Weibull model, when the time dependency parameter $p$ is a function of the variables $Z$

${ }^{17}$ Hazard ratios are obtained by computing $\exp (\hat{\beta})$

${ }^{18}$ because $\exp \left(\frac{\hat{\beta}_{\text {gender }}}{\hat{\theta}_{\text {gender }}}\right)=\exp \left(\frac{\ln 0.309}{\ln 1.333}\right)=57$ days
} 
Table 2: Cox Models With Time-Varying Effects

Model 1

Explanatory variables $\mathrm{X}$

Gender $(1=$ Male $)$

Marital status $(1=$ Married $)$

Haz. ratio p-val

Education level ( 1 = Middle-school $)$

$0.309^{*} \quad 0.010$

$0.925 \quad 0.414$

$1.037 \quad 0.590$

Employment $(1=$ Yes $)$

$0.875^{*} \quad 0.048$

Nationality $(1=$ Foreign $)$

$2.307^{* * *} \quad 0.000$

Homelessness

$1.107 \quad 0.262$

Age at release

$0.895^{* * *} \quad 0.000$

Age squared

$\mathrm{Nb}$ of prior convictions

$1.001^{* * *} \quad 0.000$

$\mathrm{Nb}$ of prior convictions squared

Penal status

No pre-trial detention (ref)

Short pre-trial detention

Classic pre-trial detention

$1.243^{* * *} \quad 0.000$

$0.994^{* * *} \quad 0.000$

$\mathrm{Nb}$ of cases

Time served (x100 days)

Libération conditionnelle

Placement à l'extérieur

Semi-liberté

Year of release $(1=1997)$

Duration dependency : $Z \cdot \ln (t)$

Gender

\section{1}

$3.163^{* * *} \quad 0.000$

$1.709+\quad 0.094$

$1.105^{*} \quad 0.013$

$0.988 \quad 0.203$

$0.264^{* *} \quad 0.006$

$0.104^{*} \quad 0.040$

$0.513 \quad 0.199$

$0.918 \quad 0.173$

Nationality

Libération conditionnelle

Placement à l'extérieur

Semi-liberté

Penal status

No pre-trial detention (ref)

Short pre-trial detention

Classic pre-trial detention

Type of initial offense

Against property (ref)

Against persons

Drug-related

Other

Prison fixed-effects

LR-test

$1.333^{* *} \quad 0.001$

$0.823^{* * *} \quad 0.000$

$1.221^{*} \quad 0.016$

$1.433+\quad 0.050$

$1.115 \quad 0.215$

Log-likelihood

Observations

$\begin{array}{cc}1 & - \\ 843^{* * *} & 0.000 \\ 0.893^{*} & 0.044\end{array}$

1

$0.989 \quad 0.431$

$0.951^{* *} \quad 0.006$

$0.929^{* * *} \quad 0.000$

$227.85^{* *} \quad 0.002$

$-8829.7$

2204

Notes : Significance levels are noted $+(10 \%), *(5 \%),{ }^{* *}$ $(1 \%)$ et $* * *(0.1 \%)$. We use Efron's method for ties. Prison fixed-effects are captured by dummies for the 171 prisons in the sample. A Likelihood-Ratio Test is performed to test their significance. 
than their older peers. However, this relation lessens (slowly) with age : for example, the hazard for a 30 -year old releasee is half that experienced by his 20 -year old peer ${ }^{19}$ ) whereas this ratio equals $36 \%$ for a prisoner aged 40 . Conversely, the instantaneous probability of recidivism is an increasing, concave function of the number of prior convictions : having one prior conviction (compared to zero) increases one's hazard by $24 \%$. This positive marginal effect lessens slowly but remains greater than $16 \%$ up to five prior convictions : thus, the hazard is $150 \%$ greater when one has five prior convictions versus none. Our estimates also suggest that both the hazard and its dynamic vary by penal status at entry : those who faced pre-trial detention display a much higher risk at release, compared to those who did not, but this risk decreases faster. More precisely, those who were incarcerated under fast procedure have a three-fold higher hazard at release ; however, this risk decreases $16 \%$ faster, which seems to suggest that part of the fast-procedure convicts display a very high criminal propensity (i.e. are embedded in a criminal lifestyle where illegal opportunities show up regularly). Our results also show that hazard increases with the number of cases which led to conviction : each additionnal case is associated with a $11 \%$ greater instantanous probability of recidivism. Conversely, hazard seems not to depend on time served, everything else equal ${ }^{20}$.

The estimates associated with the variable libération conditionnelle show that the influence of this sentence reduction is two-fold : at release, parolees experience a four time lower hazard of recidivism compared to those who did not benefit from this sentence reduction ; however, this gap lessens slowly over time (it remains significant for up to two years). The fact that parolees are much less prone to reoffend is equivocal : it may be interpreted as a causal effect of shortened time served, a causal effect of increased supervision at release ${ }^{21}$, or simply a sign of selection bias ${ }^{22}$. Our results show that the second legal measure considered, placement $\grave{a}$ l'extérieur, seems to play a very similar role on recidivism. Surprisingly, we do not find the same effect for semi-liberté (those who benefited from semi-liberté do not display significantly different recidivism patterns compared to those who did not) even though both measures are very similar ${ }^{23}$ : this result suggests that semi-liberté is not an effective way to reduce recidivism. Our estimates also show that there are significant differences between types of initial offense regarding the dynamic of recidivism : hazard decreases faster among those convicted for drugrelated and other offenses, compared to property and violent criminals. Finally, it is interesting to note that prison fixed-effects appear very significant : the type of prison (which we can not control for) is probably an important factor as detainees are allocated to different types of prison based on their profile. But we could also imagine that prison conditions differ (in terms of access to rehabilitative programs, health services, security, material conditions, visitation policy, etc.) and may alter one's path after release.

\footnotetext{
${ }^{19}$ This figure is obtained as follows : $\frac{\hat{h}_{a g e=30}}{\hat{h}_{a g e=20}}=\frac{\exp \left(30 \cdot \hat{\beta}_{a g e}+30^{2} \cdot \hat{\beta}_{a g e^{2}}\right)}{\exp \left(20 \cdot \hat{\beta}_{a g e}+20^{2} \cdot \hat{\beta}_{a g e^{2}}\right)}=0.54$

${ }^{20}$ For a discussion of the causal effect of time served, see Section 1

${ }^{21}$ In France, parolees are supervised by probation officers after release, for a period equal (at least) to the remainder of their prison sentence

${ }^{22}$ There is selection bias if parolees (treatment group) differ significantly from the others (control group) in terms of unobservable characteristics that affect the probability of being released under parole (such as motivation, reentry prospects, etc.)

${ }^{23}$ Semi-liberté and placement à l'extérieur both allow prisoners to leave prison during day hours or several consecutive days to achieve a particular task (such as work or training). The different results between these two measures may be due to the fact that placement à l'extérieur is much more selective ( $2 \%$ vs $8 \%$ of the sample) and that it generally allows longer out-of-prison spells
} 


\section{Conclusion}

This article attempts to better understand the main determinants of the recidivism dynamics. Our main contribution is to apply for the first time duration-data models to the study of this phenomenon in France.

Our results confirm the dramatic influence of gender, age, nationality, employment status and prior convictions on future offending among ex-prisoners. Our estimates notably show that females and foreigners face a particularly high risk of recidivism at release, but that these trends reverse rapidly. In terms of public policy, these results suggest that more intensive supervision and better release planning might be beneficial for these groups of prisoners. However, we do not find evidence of potential effects of marital status, education, homelessness, or time served. Our estimates highlight differences between those who served pre-trial detention and the others : we find that part of those who were incarcerated under fast procedure reoffend very quickly, even though they faced rapid convictions. It seems that imprisonment did not have the expected deterrent and rehabilitative effect, but simply incapacitated them for some time. We also find that property and violent criminals tend to reoffend faster than others. Finally, our results show that prisoners under parole and placement à l'extérieur display durably lower risk of recidivism. At this stage, however, semi-liberté does not seem to be effective in reducing recidivism.

From a methodological standpoint, many improvements can be achieved : competing-risks models, split-population models, inclusion of an unobservable heterogeneity parameter, etc. Moreover, it might be of great interest to study more precisely the role of prison conditions and social interactions (between inmates and with the outside) on reoffending. Finally, considering the current debate about recidivism in France, an important contribution would be the identification of the causal effects of parole and time served. 


\section{Appendix}

Table 3: Proportional-Hazards Tests based on the Shoenfeld residuals

\begin{tabular}{l|c|c|} 
Explanatory variables X & Model A & Model B \\
\hline Gender (1 = Male) & 0.086 & 0.038 \\
Marital status (1 = Married) & 0.669 & 0.694 \\
Education level (1 = Middle-school) & 0.618 & 0.773 \\
Employment (1 = Yes) & 0.409 & 0.350 \\
Nationality (1 = Foreign) & 0.059 & 0.002 \\
Homelessness & 0.939 & 0.655 \\
Age at release & 0.095 & 0.087 \\
Age squared & 0.253 & 0.235 \\
Nb of prior convictions & 0.459 & 0.422 \\
Nb or prior convictions squared & 0.516 & 0.430 \\
Penal status & & \\
No pre-trial detention & - & - \\
Short pre-trial detention & 0.115 & 0.054 \\
Classic pre-trial detention & 0.474 & 0.402 \\
Nb of cases & 0.064 & 0.169 \\
Type of initial offense & & \\
Against property & - & - \\
Against persons & 0.044 & 0.066 \\
Drug-related & 0.038 & 0.026 \\
Other & 0.050 & 0.159 \\
Time served (x100 days) & 0.500 & 0.354 \\
Libération conditionnelle & 0.220 & 0.043 \\
Placement à l'extérieur & 0.030 & 0.069 \\
Semi-liberté & 0.309 & 0.022 \\
Year of release (1 = 1997) & 0.609 & 0.709 \\
Prison fixed-effects & yes & no \\
\hline Observations & \multicolumn{2}{|c}{2204}
\end{tabular}

Notes : The values reported correspond to the p-values associated with the PH test for each explanatory variables, after estimating the two Cox models and regressing Shoenfeld residuals on duration 
Table 4: Cox Models With Time-Varying Effects

\begin{tabular}{|c|c|c|c|c|c|c|}
\hline \multirow[b]{2}{*}{ Explanatory variables $\mathrm{X}$} & \multicolumn{2}{|c|}{ Model 1} & \multicolumn{2}{|c|}{ Model 2} & \multicolumn{2}{|c|}{ Model 3} \\
\hline & Haz. ratio & p-val & Haz. ratio & p-val & Haz. ratio & p-val \\
\hline$\overline{\text { Gender }(1=\text { Male })}$ & $0.309^{*}$ & 0.010 & $0.317^{*}$ & 0.012 & $0.312^{*}$ & 0.012 \\
\hline Marital status ( $1=$ Married $)$ & 0.925 & 0.414 & 0.924 & 0.409 & 0.924 & 0.411 \\
\hline Education level ( 1 = Middle-school $)$ & 1.037 & 0.590 & 1.040 & 0.556 & 1.036 & 0.601 \\
\hline Employment $(1=$ Yes $)$ & $0.875^{*}$ & 0.048 & $0.875^{*}$ & 0.045 & $0.874^{*}$ & 0.046 \\
\hline Nationality ( 1 = Foreign $)$ & $2.307^{* * *}$ & 0.000 & $2.458^{* * *}$ & 0.000 & $2.149 * * *$ & 0.000 \\
\hline Homelessness & 1.107 & 0.262 & 1.102 & 0.286 & 1.097 & 0.308 \\
\hline Age at release & $0.895^{* * *}$ & 0.000 & $0.894^{* * *}$ & 0.000 & $0.895^{* * *}$ & 0.000 \\
\hline Age squared & $1.001^{* * *}$ & 0.000 & $1.001^{* * *}$ & 0.000 & $1.001^{* * *}$ & 0.000 \\
\hline $\mathrm{Nb}$ of prior convictions & $1.243^{* * *}$ & 0.000 & $1.243^{* * *}$ & 0.000 & $1.244^{* * *}$ & 0.000 \\
\hline $\mathrm{Nb}$ of prior convictions squared & $0.994^{* * *}$ & 0.000 & $0.994^{* * *}$ & 0.000 & $0.994^{* * *}$ & 0.000 \\
\hline \multicolumn{7}{|l|}{ Penal status } \\
\hline No pre-trial detention (ref) & 1 & - & 1 & - & 1 & - \\
\hline Short pre-trial detention & $3.163^{* * *}$ & 0.000 & $3.068^{* * *}$ & 0.000 & $3.200 * * *$ & 0.000 \\
\hline Classic pre-trial detention & $1.709+$ & 0.094 & 1.660 & 0.113 & $1.748+$ & 0.083 \\
\hline $\mathrm{Nb}$ of cases & $1.105^{*}$ & 0.013 & $1.105^{*}$ & 0.013 & $1.106^{*}$ & 0.012 \\
\hline Time served (x100 days) & 0.988 & 0.203 & 0.988 & 0.224 & 0.988 & 0.207 \\
\hline Libération conditionnelle & $0.264^{* *}$ & 0.006 & $0.262^{* *}$ & 0.006 & $0.264^{* *}$ & 0.006 \\
\hline Placement à l'extérieur & $0.104^{*}$ & 0.040 & $0.104^{*}$ & 0.041 & $0.104^{*}$ & 0.041 \\
\hline Semi-liberté & 0.513 & 0.199 & 0.520 & 0.209 & 0.508 & 0.194 \\
\hline \multicolumn{7}{|l|}{ Type of initial offense } \\
\hline Against property (ref) & - & - & 1 & - & 1 & - \\
\hline Against persons & & & 0.933 & 0.357 & 0.813 & 0.404 \\
\hline Drug-related & & & $0.792^{*}$ & 0.018 & 1.214 & 0.498 \\
\hline Other & & & $0.700 * * *$ & 0.000 & 1.228 & 0.417 \\
\hline Year of release $(1=1997)$ & 0.918 & 0.173 & 0.918 & 0.172 & 0.918 & 0.169 \\
\hline \multicolumn{7}{|l|}{ Duration dependency : $Z \cdot \ln (t)$} \\
\hline Gender & $1.333^{* *}$ & 0.001 & $1.327^{* *}$ & 0.002 & $1.331^{* *}$ & 0.001 \\
\hline Nationality & $0.823^{* * *}$ & 0.000 & $0.812^{* * *}$ & 0.000 & $0.834^{* * *}$ & 0.000 \\
\hline Libération conditionnelle & $1.221^{*}$ & 0.016 & $1.223^{*}$ & 0.015 & $1.221^{*}$ & 0.016 \\
\hline Placement à l'extérieur & $1.433+$ & 0.050 & $1.432+$ & 0.051 & $1.429+$ & 0.052 \\
\hline Semi-liberté & 1.115 & 0.215 & 1.111 & 0.231 & 1.117 & 0.209 \\
\hline \multicolumn{7}{|l|}{ Penal status } \\
\hline No pre-trial detention (ref) & 1 & - & 1 & - & 1 & - \\
\hline Short pre-trial detention & $0.843^{* * *}$ & 0.000 & $0.848^{* *}$ & 0.001 & $0.841^{* * *}$ & 0.000 \\
\hline Classic pre-trial detention & $0.893^{*}$ & 0.044 & $0.898+$ & 0.055 & $0.889^{*}$ & 0.039 \\
\hline \multicolumn{7}{|l|}{ Type of initial offense } \\
\hline Against property (ref) & 1 & - & - & - & 1 & - \\
\hline Against persons & 0.989 & 0.431 & & & 1.025 & 0.581 \\
\hline Drug-related & $0.951^{* *}$ & 0.006 & & & 0.920 & 0.118 \\
\hline Other & $0.929 * * *$ & 0.000 & & & $0.894^{*}$ & 0.031 \\
\hline$\overline{\text { Prison fixed-effects }}$ & \multicolumn{2}{|l|}{ yes } & \multicolumn{2}{|l|}{ yes } & \multicolumn{2}{|l|}{ yes } \\
\hline LR-test & $227.9^{* *}$ & 0.002 & $226.8^{* *}$ & 0.002 & $228.4^{* *}$ & 0.002 \\
\hline Log-likelihood & \multicolumn{2}{|c|}{-8829.7} & \multicolumn{2}{|c|}{-8832.4} & \multicolumn{2}{|c|}{-8828.5} \\
\hline $\mathrm{BIC}$ & \multicolumn{2}{|c|}{17875} & \multicolumn{2}{|c|}{17880} & \multicolumn{2}{|c|}{17896} \\
\hline Observations & \multicolumn{2}{|c|}{2204} & \multicolumn{2}{|c|}{2204} & \multicolumn{2}{|c|}{2204} \\
\hline
\end{tabular}

Notes : Significance levels are noted $+(10 \%), *(5 \%), * *(1 \%)$ et $* * *(0.1 \%)$. We use Efron's method for ties. Prison fixed-effects are captured by dummies for the 171 prisons in the sample. A Likelihood-Ratio Test is performed to test their significance. 
Table 5: Cox Models With Two Alternative Specifications Of Time Dependency

\begin{tabular}{|c|c|c|c|c|}
\hline \multirow[b]{2}{*}{ Explanatory Variables X } & \multicolumn{2}{|c|}{$f(t)=\sqrt{t}$} & \multicolumn{2}{|c|}{$f(t)=t$} \\
\hline & Haz. ratio & p-val & Haz. ratio & p-val \\
\hline Gender $(1=$ Male $)$ & 0.617 & 0.122 & 0.886 & 0.612 \\
\hline Marital Status (1 = Married) & 0.925 & 0.415 & 0.928 & 0.434 \\
\hline Education level ( 1 = Middle-school $)$ & 1.033 & 0.631 & 1.032 & 0.641 \\
\hline Employment $(1=$ Yes $)$ & $0.870^{*}$ & 0.040 & $0.869^{*}$ & 0.038 \\
\hline Nationality ( 1 = Foreign $)$ & $1.343^{*}$ & 0.023 & 1.049 & 0.627 \\
\hline Homelessness & 1.112 & 0.243 & 1.106 & 0.267 \\
\hline Age at release & $0.895^{* * *}$ & 0.000 & $0.894^{* * *}$ & 0.000 \\
\hline Age squared & $1.001^{* * *}$ & 0.000 & $1.001^{* * *}$ & 0.000 \\
\hline $\mathrm{Nb}$ of prior convictions & $1.246^{* * *}$ & 0.000 & $1.250^{* * *}$ & 0.000 \\
\hline $\mathrm{Nb}$ of prior convictions squared & $0.994^{* * *}$ & 0.000 & $0.993^{* * *}$ & 0.000 \\
\hline \multicolumn{5}{|l|}{ Penal status at entry } \\
\hline No pre-trial detention (réf) & 1 & - & 1 & - \\
\hline Short pre-trial detention & $2.001^{* * *}$ & 0.000 & $1.622^{* * *}$ & 0.000 \\
\hline Classic pre-trial detention & 1.216 & 0.265 & 1.078 & 0.563 \\
\hline $\mathrm{Nb}$ of cases & $1.105^{*}$ & 0.013 & $1.103^{*}$ & 0.015 \\
\hline Time served (x100 days) & 0.987 & 0.192 & 0.988 & 0.208 \\
\hline Libération conditionnelle & $0.503^{* *}$ & 0.003 & $0.648^{* *}$ & 0.007 \\
\hline Placement à l'extérieur & $0.301^{*}$ & 0.015 & $0.470^{*}$ & 0.024 \\
\hline Semi-liberté & 0.513 & 0.672 & 0.741 & 0.150 \\
\hline Year of release $(1=1997)$ & 0.915 & 0.153 & 0.909 & 0.125 \\
\hline \multicolumn{5}{|l|}{ Duration dependency : $Z \cdot f(t)$} \\
\hline Gender & $1.045^{* *}$ & 0.008 & $1.001^{*}$ & 0.035 \\
\hline Nationality & $0.974^{* * *}$ & 0.000 & $0.999^{* *}$ & 0.002 \\
\hline Libération conditionnelle & $1.024^{*}$ & 0.015 & $1.000^{*}$ & 0.035 \\
\hline Placement à l'extérieur & $1.048^{*}$ & 0.016 & $1.001^{*}$ & 0.015 \\
\hline Semi-liberté & 1.017 & 0.116 & $1.000^{*}$ & 0.049 \\
\hline \multicolumn{5}{|l|}{ Penal status } \\
\hline No pre-trial detention (réf) & 1 & - & 1 & - \\
\hline Short pre-trial detention & $0.975^{* * *}$ & 0.000 & $0.999 * *$ & 0.001 \\
\hline Classic pre-trial detention & $0.986+$ & 0.061 & $1.000+$ & 0.076 \\
\hline \multicolumn{5}{|l|}{ Type of initial offense } \\
\hline Against property (réf) & 1 & - & 1 & - \\
\hline Against persons & 1.001 & 0.877 & 1.000 & 0.310 \\
\hline Drug-related & $0.985^{* *}$ & 0.003 & $0.999^{* *}$ & 0.002 \\
\hline Other & $0.982^{* * *}$ & 0.000 & $0.999^{* *}$ & 0.002 \\
\hline \multirow{2}{*}{$\begin{array}{l}\text { Prison fixed-effects } \\
\text { LR-test }\end{array}$} & \multicolumn{2}{|l|}{ yes } & \multicolumn{2}{|l|}{ yes } \\
\hline & $231.6^{* *}$ & 0.002 & $232.5^{* *}$ & 0.002 \\
\hline$\overline{\text { Log-likelihood }}$ & -8831 & & -8837 & \\
\hline Observations & 2204 & & 2204 & \\
\hline
\end{tabular}

Notes : Significance levels are noted $+(10 \%), *(5 \%),{ }^{* *}(1 \%)$ et $* * *(0.1 \%)$. We use Efron's method for ties. Prison fixed-effects are captured by dummies for the 171 prisons in the sample. A Likelihood-Ratio Test is performed to test their significance. 


\section{Bibliography}

Amirault, J. And Lussier, P. 2011. Population heterogeneity, state dependence and sexual offender recidivism: The aging process and the lost predictive impact of prior criminal charges over time. Journal of Criminal Justice 39, 4, 344-354.

Barlow, H. and Kauzlarich, D. 2010. Explaining Crime: A Primer in Criminological Theory. G - Reference, Information and Interdisciplinary Subjects Series. Rowman \& Littlefield.

Bayer, P., Hualmarsson, R., And Pozen, D. 2009. Building criminal capital behind bars: Peer effects in juvenile corrections. The Quarterly Journal of Economics 124, 1, 105-147.

Becker, G. S. 1968. Crime and punishment: An economic approach. Journal of Political Economy 76, 169.

Bernburg, J. G., Krohn, M. D., And Rivera, C. J. 2006. Official labeling, criminal embeddedness, and subsequent delinquency: A longitudinal test of labeling theory. Journal of Research in Crime and Delinquency 43, 1, 67-88.

Bierens, H. J. and Carvalho, J. R. 2002. A competing risk analysis of recidivism. Working paper.

BIERIE, D. 2009. Cost matters: a randomized experiment comparing recidivism between two styles of prisons. Journal of Experimental Criminology 5, 371-397.

Bowles, R. A. And Florackis, C. 2007. Duration of the time to reconviction: Evidence from UK prisoner discharge data. Journal of Criminal Justice 35, 4, 365-378.

Box-Steffensmeier, Janet M \& Jones, B. S. 2004. Event history modeling: A guide for social scientists. Cambridge University Press, New York.

Chen, M. K. And Shapiro, J. M. 2007. Do harsher prison conditions reduce recidivism? A discontinuity-based approach. American Law and Economics Review 9, 1, 1-29.

DeAngelo, G. And Charness, G. 2012. Deterrence, expected cost, uncertainty and voting: Experimental evidence. Journal of Risk and Uncertainty 44, 73-100.

Di Tella, R. And Schargrodsky, E. 2013. Criminal recidivism after prison and electronic monitoring. Journal of Political Economy forthcoming.

Drago, F. And Galbiati, R. 2012. Indirect effects of a policy altering criminal behavior: Evidence from the Italian prison experiment. American Economic Journal: Applied Economics 4, 2, 199-218. 
Drago, F., Galbiati, R., and Vertova, P. 2009. The deterrent effects of prison: Evidence from a natural experiment. Journal of Political Economy 117, 2 (04), 257-280.

Drago, F., Galbiati, R., and Vertova, P. 2011. Prison conditions and recidivism. American Law and Economics Review 13, 1, 103-130.

Duwe, G. And Clark, V. 2013. Blessed be the social tie that binds: The effects of prison visitation on offender recidivism. Criminal Justice Policy Review 24, 3, 271-296.

Escarela, G., Francis, B., And Soothill, K. 2000. Competing risks, persistence and desistance in analyzing recidivism. Journal of Quantitative Criminology 16, 4, 385-414.

Farrington, D. P. 2003. British randomized experiments on crime and justice. The Annals of the American Academy of Political and Social Science 589, 1, 150-167.

Folkard, M. S., Smith, D. E., And Smith, D. D. 1976. Impact : Volume 2, the results of the experiment. Tech. rep., Home Office Research Study n 36.

Hirschi, T. 1969. Causes of Delinquency. Campus (Berkeley, Calif.). University of California Press.

Kensey, A. And Benaouda, A. 2011. Les risques de récidive des sortants de prison. une nouvelle évaluation. Cahiers d'études pénitentiaires et criminologiques 36.

Kensey, A. And Tournier, P.-V. 2002. Arithmétique de l'exécution des peines. DAP-PMJ1 : Travaux $\&$ Documents $\mathrm{n}^{\circ} 60$.

Kensey, A. And Tournier, P.-V. 2005. Prisonniers du passé ? cohorte des personnes condamnées, libérées en 1996-1997 : examen de leur casier judiciaire 5 ans après la levée d'écrou (échantillon national aléatoire stratifié selon l'infraction). Direction de l'Administration Pénitentiaire, Coll. Travaux \& Documents, 348 pages.

Kim, J. I., Benson, B. L., Rasmussen, D. W., And Zuehlke, T. W. 1993. An economic analysis of recidivism among drug offenders. Southern Economic Journal 60, 1 (July), 169183.

Kubrin, C. E. And Stewart, E. A. 2006. Predicting who reoffends: The neglected role of neighborhood context in recidivism studies. Criminology 44, 1, 165-197.

Langan, P. A. And Levin, D. J. 2002. Recidivism of prisoners released in 1994. Tech. rep., U.S. Dept. of Justice, Office of Justice Programs, Bureau of Justice Statistics.

Manski, C. F. 2000. Economic analysis of social interactions. Journal of Economic Perspectives 14, 3 (Summer), 115-136.

Maurin, E. AND Ouss, A. 2009. Sentence reductions and recidivism: Lessons from the Bastille Day quasi experiment. IZA Discussion Papers 3990, Institute for the Study of Labor (IZA). Feb.

Sampson, R. J. And Laub, J. H. 2003. Desistance from crime over the life course. In Handbook of the Life Course, J. Mortimer and M. Shanahan, Eds. Handbooks of Sociology and Social Research. Springer US, 295-309. 
Schmidt, P. And Witte, A. D. 1989. Predicting criminal recidivism using 'split population' survival time models. Journal of Econometrics 40, 1 (January), 141-159.

Skardhamar, T. and Telle, K. 2009. Life after prison: The relationship between employment and re-incarceration. Discussion Papers 597, Research Department of Statistics Norway. Oct.

Svensson, R., Weerman, F. M., Pauwels, L. J., Bruinsma, G. J., and Bernasco, W. 2013. Moral emotions and offending: Do feelings of anticipated shame and guilt mediate the effect of socialization on offending? European Journal of Criminology 10, 1, 22-39.

UGGEN, C. 2000. Work as a turning point in the life course of criminals: A duration model of age, employment, and recidivism. American Sociological Review 65, 4, 529-546.

Van Winden, F. And Ash, E. 2012. On the behavioral economics of crime. Review of Law and Economics 8, 1, 181-213.

Zamble, E. And Quinsey, V. L. 1997. The Criminal Recidivism Process. Cambridge Criminology Series. Cambridge University Press. 